\title{
ANALISIS KEBIJAKAN PERCEPATAN PEMBANGUNAN SOSIAL EKONOMI DAERAH TERTINGGAL ( P2SEDT)
}

\author{
Meri Enita Puspita Sari \\ Dosen Tetap Program Studi Ilmu Pemerintahan UNRIKA Batam
}

\section{Latar Belakang}

Kemiskinan dapat didefinisikan sebagai kondisi dimana seseorang atau sekelompok orang, laki-laki dan perempuan, tidak terpenuhi hak-hak dasarnya untuk mempertahankan dan mengembangkan kehidupan yang bermartabat. Pemahaman mengenai "kemiskinan" mestilah beranjak dari pendekatan berbasis hak (right based approach). Dalam pemahaman ini harus diakui bahwa seluruh masyarakat, baik laki-laki maupun perempuan, mempunyai hak-hak dasar yang sama. Kemiskinan juga harus dipandang sebagai masalah multidimensional, tidak lagi dipahami hanya sebatas ketidakmampuan ekonomi, tetapi juga kegagalan dalam memenuhi hak-hak dasar dan perbedaan perlakuan bagi seseorang atau sekelompok orang dalam menjalani kehidupan secara bermartabat. Pendekatan right based approach mengandung arti bahwa negara berkewajiban untuk menghormati, melindungi, dan memenuhi hak-hak dasar masyarakat miskin secara bertahap.

Hak-hak dasar yang diakui secara umum antara lain meliputi terpenuhinya kebutuhan pangan, kesehatan, pendidikan, pekerjaan, perumahan, air bersih, pertanahan, sumberdaya alam dan lingkungan hidup, rasa aman dari perlakuan atau ancaman tindak kekerasan, dan hak untuk berpartisipasi dalam kehidupan sosial politik, baik bagi perempuan maupun bagi laki-laki. Hak-hak dasar tidak berdiri sendiri tetapi saling mempengaruhi satu sama lain sehingga tidak terpenuhinya satu hak dapat mempengaruhi pemenuhan hak lainnya. Keinginan menangggulangi kemiskinan sebenarnya bukanlah hal baru. Dari lembar-lembar PJP I, terlihat bahwa menjelang pelaksanaan Repelita III (1979/1980-1983/1984) , pemerintah telah encanangkan dua pokok kebijakansanaan pembangunan yaitu : (1) mengurangi jumlah penduduk yang hidup di bawah garis kemiskina dan (2) melaksanakan delapan jalur pemerataan.

\section{Situasi Kemiskinan di Indonesia dan Permasalahannya}

Kemiskinan, yang antara lain ditandai oleh banyaknya penduduk yang hidup atau sangat rentan jatuh ke bawah garis kemiskinan, masih merupakan permasalahan yang dihadapi oleh bangsa Indonesia. Perkiraan BPS menunjukkan bahwa pada tahun 2003 terdapat sekitar 34,7 juta jiwa atau sekitar 17,4\% dari jumlah penduduk yang berada di bawah garis kemiskinan (tingkat pengeluaran yang diperlukan untuk dapat mengkonsumsi makanan setara $2100 \mathrm{Kkal}$ sehari dan pengeluaran minimal untuk kebutuhan dasar lainnya). Bila acuan kemiskinan yang digunakan adalah tingkat pengeluaran kurang dari US\$ 2 PPP per orang per hari, maka jumlahnya menjadi jauh lebih besar. Berdasarkan standar acuan tersebut, Bank Dunia memperkirakan jumlah penduduk miskin di Indonesia adalah sekitar 53,4\% atau 114,8 juta jiwa. Masalah kemiskinan juga ditandai oleh rendahnya Human Development Index (HDI), yang menggambarkan mutu kehidupan masyarakat. Dibandingkan dengan beberapa Negara tetangga seperti Malaysia, Thailand, dan Filipina, nilai HDI Indonesia pada tahun 2002 masih lebih rendah. Posisi HDI Indonesia saat ini hamper setara dengan Vietnam yang sepuluh tahun yang lalu jauh tertinggal di bawah Indonesia. Meskipun kita sedikit lebeh baik dari pada Vietnam pada Indikator pendapatan, akses terhdap air bersih dan kecukupan gizi balita, namun kita masih berada dibawah Vietnam pada Indokator pendidikan dan kesehatan.

Hal ini penanda kemiskinan adalah adanya ketimpangan antara wilayah. Secara jumalah, kemiskinan terbesar berada di Jawa dan Bali karena jumlah penduduknya yang 
mencapai $60 \%$ penduduk Indonesia. Namun, persentase kemiskinan diluar jawa, khususnya kawasan timur Indonesia jauh laebih tinggi. Pada tahun 2003, kemiskinan di DKI Jakarta hanya sekitar 3,4 \%, sedangkan di Papua mencapai sekitar 39\%. Kemiskinan di Indonesia juga sebagian besar dihadapi oleh penduduk didaerah pedesan, yang pada umunya bekerja disektor pertanian. Pada tahun 2003 jumlah penduduk miskin dipedasaan mencapai $67 \%$.

Situasi kemiskinan yang tertangkap dalam angka-angka diatas hanyalah ukuran kemiskinan yang didasarkan atas permasalahan pendapatan atau ekonomi belaka. Lebih lanjut daripada itu, permasalahan kemiskinan perlu dilihat dari aspek kegagalan dalam pemenuhan hak dasar, serta ketidakadilan dan ketidaksetaraan. Beberapa permasalahan yang menyebabkan terjadinya kegagalan dalam pemenuhan hak-hak dasar antara lain :

1. Terbatasnya kecukupan dan mutu pangan.

2. Terbatasnya akses dan rendahnya mutu layanan kesehatan.

3. Terbatasnya akses dan rendahnya mutu layanan pendidikan.

4. Terbatasnya kesempatan kerja dan berusaha.

5. Terbatasnya akses layanan perumahan.

6. Terbatasnya akses air bersih dan sanitasi.

7. Lemahnya kepastian kepemilikan dan pengusaan tanah.

8. Memburuknya kondisi SDA dan lingkungan hidup.

9. Lemahnya jaminan rasa aman

10. Lemahnya Partisipasi.

\section{Perkembangan Tingkat Kemiskinan di Indonesia tahun 1996-2006}

Jumlah dan persentase penduduk miskin pada periode 1996-2006 berfluktuasi dari tahun ke tahun. Pada periode 1996-1999 jumlah penduduk miskin meningkat sebesar 13,96 juta arena krisis ekonomi, yaitu dari 34,01 juta pada tahun 1996 menjadi 47,97 juta pada tahun 1999. Persentase penduduk miskin meningkat dari 17,47 persen menjadi 23,43 persen pada periode yang sama.

Pada periode 2000-2005 jumlah penduduk miskin cenderung menurun dari 38,70 juta pada tahun 2000 menjadi 35,10 juta pada tahun 2005. Secara relatif juga terjadi penurunan persentase penduduk miskin dari 19,14 persen pada tahun 2000 menjadi 15,97 persen pada tahun 2005. Namun pada tahun 2006, terjadi kenaikan jumlah penduduk miskin yang cukup drastis, yaitu dari 35,10 juta orang (15,97 persen) pada bulan Februari 2005 menjadi 39,30 juta (17,75 persen) pada bulan Maret 2006. Penduduk miskin di daerah perdesaan bertambah 2,11 juta, sementara di daerah perkotaan bertambah 2,09 juta orang.

Peningkatan jumlah dan persentase penduduk miskin selama Februari 2005-Maret 2006 terjadi karena harga barang-barang kebutuhan pokok selama periode tersebut naik tinggi, yang digambarkan oleh inflasi umum sebesar 17,95 persen. Akibatnya penduduk yang tergolong tidak miskin namun penghasilannya berada disekitar garis kemiskinan banyak yang bergeser posisinya menjadi miskin.

\section{Perkembangan Tingkat Kemiskinan Maret 2006-Maret 2007}

Jumlah penduduk miskin di Indonesia pada bulan Maret 2007 sebesar 37,17 juta orang (16,58 persen). Dibandingkan dengan penduduk miskin pada Maret 2006 yang berjumlah 39,30 juta (17,75 persen), berarti jumlah penduduk miskin turun sebesar 2,13 juta. Meskipun demikian, persentase penduduk miskin pada Maret 2007 masih lebih tinggi dibandingkan keadaan Februari 2005, dimana persentase penduduk miskin sebesar 15,97 persen. Jumlah penduduk miskin di daerah perdesaan turun lebih tajam dari pada daerah perkotaan. Selama periode Maret 2006-Maret 2007, penduduk miskin di daerah perdesaan berkurang 1,20 juta, sementara di daerah perkotaan berkurang 0,93 juta orang. Persentase 
penduduk miskin antara daerah perkotaan dan perdesaan tidak banyak berubah. Pada bulan Maret 2006, sebagian besar $(63,13$ persen) penduduk miskin berada di daerah perdesaan, sementara pada bulan Maret 2007 persentase ini hampir sama yaitu 63,52 persen.

\section{Percepatan Pembangunan Sosial Ekonomi Daerah Tertinggal (P2SEDT) sebagai salah satu upaya Pemerintah dalam Penanggulangan Kemiskinan.}

Berdasarkan definisi kemiskinan dan situasi kemiskinan yang ada di Indonesia yang telah dipaparkan diatas, Pemerintah mengambil kebijakan penanggulangan kemiskinan untuk menangani pembangunan social ekonomi daerah tertinggal sebagai bentuk penindaklanjutan program kemiskinan sebelumnya. P2SEDT diharapkan mampu mewujudkan pengurangan angka kemiskinan, pengangguran yang semuanya bermuara pada peningkatan kesejahteran masyarakat. Hal itu dapat terwujud dengan percepatan pembangunan khususnya di daerahdaerah tertinggal.

Dalam konteks tersebut. Pembangunan daerah tertinggal merupakan upaya terencana untuk mengubah suatu daerah yang dihuni oleh komunitas dengan berbagai permasalahan social ekonomi dan keterbatsan fisik, menjadi daerah yang mau dengan komunitas yang kualitas hidupnya sama atau tidak jauh tertinggal dibandingkan dengan masyarakat Indonesia lainnya. Pembangunan daerah tertinggal tidak hanya meliputi aspek ekonomi, tetapi juga aspek social, budaya dan keamanan (bahkan menyangkut hubungan antara daerah tertinggal dengan daerah maju). Disamping itu kesejahteraan kelompok masyarakat yang hidup didaerah tertinggal memerlukan perhatian dan keberpihakkan yang besar dari pemerintah.

Kementrian Negara Pembangunan Daerah Tertinggal (KPDT) telah mengembangkan berbagai instrument percepatan pembangunan melalui sekian banyak program pembangunan, tentunya dengan beragam pendekatan yang disesuaikan dengan kareteristik dan topografi daerah tertinggal. Selanjutnya dalam RPJM 2004-2009 telah ditetapkan 199 kabupaten sebagai daerah tertinggal. Secara kuantitatif jumlah daerah tertinggal tersebut adalah sebanyak $44 \%$ dari 457 kebupaten/kota di Indonesia. Namun demikian secara ekonomi, peranan daerah tertinggal terhadap ekonomi nasional sangat kecil.

Berdasarkan sebaran wilayahnya, sebanyak 123 kabupaten atau 63\% daerah tertinggal berada dikawasan Timur Indonesia, 58 Kabupaten atau $28 \%$ berada di Pulau Sumatera, dan 18 Kabupaten atau $8 \%$ berada di pulau Jaw dan Bali. Diluar kategori ketertinggalan tersebut, juga terdapat sejumlah kawasan yang dihuni oleh Komunitas Adat Terpencil yaitu kelompok social budaya yang bersifat local dan terpencar, yang pada umumnya kawasan tersebut masih belum tersentuh oleh jaringan dan pelayanan sosial, ekonomi bahkan pemerintahan.

Melihat dari data yang didapat dapat disimpulakan bahwa daerah-daerah yang tertinggal berada diluar jawa. Harus ada keadilan dalam meningkatkan kesejahteran rakyat dikawasan-kawasan yang tertinggal. Sebanyak 2.717 desa atau perkampungan yang ada di Sumatera Utara tergolong desa atau perkampungan tertinggal. Dari jumlah tersebut sebanyak 1.899 terletak dikawasan yang bukan tertinggal dan 800 lebih berada dikawasan yang memang tertinggal. Penyebab ketertinggal tersebut masih didominasi persoalan infrastruktur jalan yang menghubungi daerah tersebut dengan daerah luar. Kondisi ini diperparah jalan di Sumatera Utara yang rusak berat. Sehingga dapat disimpulkan bahwa penyebab ketertinggalan tersebut masih didominasi persoalan infrastruktur jalan yang menghubungi daerah tersebut dengan dunia luar.

Berbagai upaya yang telah dilakukan oleh Kemeneg PDT selama ini dirasakan belum menyebar kepada seluruh lapisan masyarakat sehingga menimbulkan kesan bahwa pemerintah belum melakukan upaya pembangunan secara osistematis di daerah tertinggal. Salah satu penyebabnya adalah belum berperannya kelembagaan masyarakat yang dibangun selama ini baik dalam perencanaan, pelaksanaan maupun pengendalian. Oleh karena itu 
Pemerintah membuat kebijakan penanggulangan kemiskinan melalui Percepatan Pembangunan Sosial Ekonomi Daerah Tertinggal (P2SEDT) sebagai upaya untuk mengentaskan kemiskinan dengan meningkatkan kesejahteraan rakyat dikawasan-kawasan yang tertinggal dengan adil dan merata.

\section{Program P2SEDT dan Tujuan P2SEDT}

Program P2SEDT adalah salah satu program pemerintah untuk mengentaskan kemiskinan di daerah-daerah tertinggal dengan menggunakan dana lebih kurang 2.400 Triliun untuk mengentaskan 199 kabupaten tertinggal di Indonesia walaupun kemampuan Pemerintah Pusat hanya sekitar 20 persen atau RP. 480 Triliun. Sehingga dibutuhkan dukungan dari Pemerintah Provinsi maupun Pemerintah Kabupaten serta dorongan dari investasi swasta. Kementrian PDT tahun 2007 mengalokasikan dana stimulan melalui program ini sebesar RP. 11,73 Miliar yang didistribusikan melalui rekening 115 lembaga social di 23 kabupaten daerah tertinggal di 11 Provinsi. Dan stimulant tersebut digunakan untk pengutan kelembagaan, pelatihan keterampila serta modal usaha. Selain untuk mengentaskan kemiskinan dengan pengurangan anga kemiskinan, Program ini juga bertujuan mengurangi pengangguran dan meningkatkan kesejahteraan masyarakat dengan memberikan modal usaha sebagai upaya pemerintah dalam memberdayakan masyarakat.

P2SEDT merupakan salah satu program yang diluncurkan Kementrian PDT yang secara umum bertujuan menstimulasi aktivitas dan kapasitas lembaga social ekonomi dalam membina kelompok-kelompok masyarakat guna meningkatkan kesejahteraan masyarakat didaerah tertinggal. Kelompok masyarakat yang ditetapkan sebagai penerima bantuan itu berupa lembaga social ekonomi yang memiliki jumlah anggota maksimal 25 orang berdasarkan rekomendasi Pemerintah Daerah setempat. Salah satu ketentuannya adalah anggota masyarakat yang berfrofesi sebagai petani, perajin, peternak, nelayan dan pedagang kecil. Penggunaan dana tersebut harus dipertanggungjawabkan degan benar serta kelompok yang bersangkuatan tidak sedang mendapat bantuan social dari lembaga lain pada tahun yang sama.

Arah kebijakan P2SEDT Dalam mengentaskan kemiskinan di Indonesia diperlukan kerja keras pemerintah untuk menanggulangi kemiskinan didaerah-daerah yang masih dikategorikan daerah tertinggal. Prioritas pembangunan dan akselerasi percepatan pembangunan menjadi amat kursial untuk ditekankan. Dalam kurun waktu 2008-2009, KPDT akan menekankan pada dua pendekatan percepatan pembangunan yaitu "Pendekatan Wilayahan dan Pendekatan Sinergitas Sektoral", yang dikoordinasikan melalui Rencana Aksi nasional Percepatan Pembangunan Daerah Tertinggal (RAN PPDT).

\section{Permasalahan Pembangunan Daerah tertinggal}

P2SEDT seperti dijelaskan diatas merpakan program yang bertujuan untuk menstimulasi aktivitas dan kapasitas lembaga social ekonomi dalam membina kelompokkelompok masyarakat guna meningkatkan kesejahteraan masyarakat didaerah tertinggal. Program P2SEDT diharapkan mampu untuk mengentaskan permasalahan-permasalahan kemiskinan yang ada di Indonesia. Adapun Permasalahan kemiskinan tersebut adalah :

a. Masih terdapat kesenjangan (disparitas) pembangunan antarwilayah yang ditandai dengan adanya wilayah-wilayah tertinggal.

b. Hasil identifikasi menunjukkan terdapat 199 (43\%) kabupaten tertinggal, dengan konsentrasi kawasan timur Indonesia 62\% dan kawasan barat Indonesia $38 \%$. 
c. Perhatian pembangunan kawasan perbatasan yang masih menitikberatkan pendekatan keamanan dibidang kesejahteraan.

$d$. Permasalahan aspek pengembangan ekonomi local yaitu keterbatasan pengelolaan sumber daya local dan belum terintegrasinya dengan kawasan pusat pertmbuhan.

e. Permasalahan aspek pengembangan sumber daya manusia yaitu rendahnya kualitas sumber daya manusia.

f. Permasalahan aspek kelembagaan, terutama rendahnya kemampuan kelembagaan aparat dan masyarakat.

g. Permasalahan aspek sarana dan prasarana terutama transportasi darat, laut dan udara, telekomunikasi dan energy serta ketersolasian daerah.

$h$. Permasalahan aspek karateristik daerah terutama berkaitan degan daerah rawan bencana (kekeringan, banjir, longsor, kebakaran hutan, gempa bumi, dll) serta rawan konflik social.

\section{Strategi-Stretegi yang digunakan oleh P2SEDT untuk mengentaskan kemiskinan adalah :}

Untuk mengetaskan permasalahan kemiskinan di Indonesia. Pemerintah harus menggunakan stretegi-strategi khusus dalam menanggulangi kemiskinan melalui P2SEDT ini. Untuk mengatasi permasalahan pembangunan daerah tertinggal dilakukan dengan strategi dasar melalui empat pilar yaitu :

a. Pilar Pertama, meningkatkan kemandirian masyarakat dan daerah tertinggal dilakukan melalui :

1. Pengembangan ekonomi lokal.

2. Pemberdayaan masyarakat.

3. Penyediaan prasarana dan sarana local/pedesaan.

4. Peningkatan kapasitas kelembagaan pemerintah daerah, dunia usaha dan masyarakat.

b. Pilar Kedua, mengoptimalkan pemanfatan potensi wilayah, dilakukan melalui :

1. Penyediaan informasi potensi sumber daya wilayah.

2. Pemanfaatan teknologi tepat guna.

3. Peningkatan investasi dan kegiatan produksi.

4. Pemberdayaan dunia usaha dan UMKM.

5. Pembangunan kawasan produksi.

c. Pilar Ketiga, memperkuat integrasi ekonomi antara daerah tertinggal dan daerah maju, dilakukan melalui :

1. Pengembangan jaringan ekonomi antar wilayah.

2. Pengembangan jaringan prasarana antar wilayah.

3. Pengembangan pusat-pusat pertumbuhan ekonomi daerah.

d. Pilar Keempat, meningkatkan penanganan daerah khusus yang memiliki karekteristik "keterisolasian", dilakukan melalui :

1. Pembukaan keterisolasian daerah (pedalaman, pesisir, dan pulau kecil terpencil).

2. Penanganan komunitas adat terasing.

3. Pembangunan daerah perbatasan dan pulau-pulau kecil.

Strategi-strategi yang dilakukan oleh pemeritah dalam program P2SEDT tersebut tidak akan tepat guna apabila masyarakat tidak ikut bekerjasama didalam menjalankan program yang telah dibuat, oleh karena itu dibutuhkan dukungan penuh dari masyarakat luas. Keberhasilan tersebut harus didukung oleh :

1. Sikap alternative bagi daerah tertinggal dalam aspek kebijakan, perencanaan, penganggaran, pelaksanaan, koordinasi dan pengendalian. 
2. Keselarasan dan keterpaduan diantara 3 (tiga) level pemerintahan, yaitu pemerintah, pemerintah provinsi, dan pemerintah kabupaten dalam penentuan agenda kegiatan, perencanaan, pelaksanaan, monitoring dan evaluasi pembangunan daerah tertinggal.

3. Program dan instrument pelaksanaan serta alokasi anggaran dari kementrian/lembaga yang memadai untuk memenuhi kebutuhan pembagunan daerah tertinggal.

4. Skema penandaan khusus bagi pembangunan daerah tertinggal.

5. Adanya inisiatif provinsi dan kabupaten dalam menangani ketertinggalan daerahnya sesuai potensi, masalah dan kewenangan yang dimiliki.

6. Adanya strategi yang memiliki legalitas yang kuat untuk diacu oleh kementrian dan lembaga terkait.

7. Adanya pengaturan kewenangan, tanggung jawab, alokasi anggaran, mekanisme kerja, dan hubungan kerja antar instansi.

8. Adanya insentif yang memadai bagi mereka yang bekerja di daerah terpencil dan perbatasan.

\section{Pendekatan-pendekatan yang digunakan dalam Program P2SEDT}

Diatas telah dijelaskan bagaimana startegi-strategi yang ada dalam program P2SEDT, dimana strategi tersebut dimaksudkan untuk dapat membantu pemerintah dalam keberhasilan mengentaskan kemiskinan. Selain strategi-strategi diatas, juga terdapat pendekatanpendekatan yang digunakan dalam Program P2SEDT dimana dalam kurun waktu tahun 20082009, KPDT akan menekankan pada dua pendekatan percepatan pembangunan, yaitu pendekatan Wilayahan dan pendekatan sinergitas sektoral, yang dikoordinasikan melalui Rencana Aksi Nasional percepatan pembangunan Daerah Tertinggal ( RAN PPDT) kedua pendekatan tersebut akan difokuskan pada 5 prioritas yaitu :

\section{a. Green Belt}

adalah tema strategi dalam mempercepat pembangunan diwilayah perbatasan. Instrumen kebijakan dalam percepatan pembangunan wilayah perbatasan adalah program pengembangan wilayah perbatasan (P2WP). Pembangunan daerah tertinggal mempunyai sasaran penanganan daerah perbatasan untuk memperkecil disintegrasi sekaligus meningkatkan kesejahteraan masyarakat diwilayah perbatasan dengan Negara tetangga. Pelaksanaan pembangunan Beranda Depan Bangsa melalui program penanganan kareteristik khusus daerah serta kegiatan P2WP dengan program pemberdayaan masyaraka degan kegiatan P2DTK di daerah tertinggal.

b. Green Energy (Desa terang)

merupakan tema strategis dalam mempercepat pembangunan infrastruktur desa tertinggal dikabupaten tertinggal, Instrumen kebijakan untuk mempercepat pembangunan infrastruktur perdesaan adalah program peningkatan sarana dan prasarana perdesaan (P2IP).

Pembangunan Perdesaan Daerah Tertinggal yang belum tersentuh aliran listrik PLN, melalui pembangunan PLTS, PLTH serta dengan pemanfaatan energy alternative lainnya untuk mengurangi ketergantungan pemanfaatan fosil yang sudah langka dan mahal. Pelaksanaan pembangunan Desa Terang melalui Program Pengurangan Keterisolasian Daerah melalui kegiatan P2IPDT dengan lokasi di daerah Tertinggal serta program Ekonomi Lokak dengan Kegiatan P4DT.

c. Green Movement (kader penggerak pembangunan satu bangsa-KPPSB)

adalah tema strategis untuk mempercepat pembangunan dikawasan perdesaan di kabupaten tertinggal, Instrumen kebijakan untuk percepatan pembangunan kawasan perdesaan di kabupaten tertinggal adalah percepatan pembangunan social ekonomi di daerah tertinggal (P2SEDT), dan percepatan Pembangunan Daerah Tertinggal dan Khusus ( P2DTK). 
Pembangunan Daerah Tertinggal mempunyai sasaran pengutan kelembagaan, selama ini kelembagaan yang ada kuarang dimanfaatkan sebagai motor penggerak Pembangunan Daerah Tertinggal. Pelaksanaannya melalui program peningkatan Kapasitas Kelembagaan dengan kegiatan P2SEDT dengan lokasi di daerah tertinggal.

\section{d. Green Bank}

merupakan tema strategi untuk memperkuat pendanaan guna mempercepatan pembangunan daerah tertinggal dan terpencil. Termasuk didalamnya adalah merumuskan kebijakan tentang insentif pendanaan bagi pembangunan daerah tertinggal melalui skim pembiayaan dana Alokasi Khusus (DAK) kabupaten tertinggal

Pembangunan Daerah Tertinggal mempunyai sasaran untuk pendirian Mikro Banking di pedesaan, sekaligus sebagai upaya pengembangan ekonomi local di perdesaan. Selama ini masyarakat dipedesaan sangat lemah dibidang permodalan. Pelaksanaan pendirian mikro banking meui program pengembangan Ekonomi Lokal termasuk dalam kegiatan P2KPDT di daerah tertinggal.

\section{e. Green Estate}

Adalah tema strategis untuk percepatan pembangunan produktivitas wilayah di kabupaten tertinggal. Adapun instrument kebijakannya adalah percepatan pembangunan Pusat pertumbuhan Daerah Tertinggal (P4DT). Pembangunan daerah tertinggal mempeunyai sasaran untuk penanaman satu juta pohon dimulai pada tahun 2008, sekaligus pengurangan dampak pemanasan global, dengan tanaman pohon produksi, seperti : karet dan sawit unggul serta pelestarian lingkungan hidup dengan penanaman pohon mangrove. Pelaksanaan Green Estate Pembangunan Daerah tertinggal melalui program Ekonomi Lokal dengan kegiatan P2KPDT di daerah tertinggal dan kegiatan P4DT di daerah tertinggal.

Dalam Materi kuliah yang telah disampaikan oleh Dr. Ambar Widaningrum, terdapat pendekatan-pendekatan dalam pengentasan kemiskinan, yaitu terdapat 4 (empat) pendekatan diantaranya : Self-sufficiency approach, Culture approach, Employment/income approach dan Spatial integration approach. Namun menurut saya, pendekatan yag cocok digunakan dalam P2SEDT adalah :

\section{Pendekatan pemenuhan mandiri (Self-sufficiency approach)}

- Membantu pengentasan kemiskinan dengan pendekatan struktural

- Berusaha memutuskan ketergantungan kaum miskin dengan institusi/organisasi/sistem sosial

- Pemberdayaan dengan membantu kaum miskin mengorganisir diri, meningkatkan kemampuan, memperjuangkan kepentingan melalui system.

Dimana dengan pendekatan ini, masyarakat mampu mandiri dengan pelatihan dan modal yang diberikan oleh pemerintah. Pemberdayaan masyarakat benar-benar ditangani dengan strategi-strategi yang mampu mengeluarkan merekan dari kemiskinan.

\section{Pendekatan integrasi wilayah (Spatial integration approach)}

- Pengentasan kemiskinan berkaitan dengan ketimpangan desa dan kota, pusat-pinggiran

- Mengintegrasikan eko-sos-pol desa-kota, pusat-pinggiran

- Memperkuat keterkaitan (linkages) melalui pengaturan distribusi aliran sumberdaya

Pendekatan ini mampu mengentaskan kemiskinan di daerah-daerah tertinggal, mengingat daerah-daerah tertinggal tersebut berada di daerah-daerah terpencil yang jarang tersentuh atau sama sekali tidak tersentuh oleh pemerintah. Perbedaan geografis wilayah dan budaya membuat sumber daya yang diperlukan daerah tidak terpenuhi. Oleh karena itu, pendekatan ini mampu mendukung strategi-strategi yang ada dalam program P2SEDT.

\section{Contoh Daerah Tertinggal yang menjadi sasaran dalam Program P2SEDT (Provinsi Jambi)}


Saat ini sebanyak 199 kabupaten di Indonesia masih dalam kategori daerah tertinggal termasuk Kabupaten Sarolangun dan Tanjung Jabang Timur di Provinsi Jambi. Sebagai contoh, dalam kurun waktu 3 tahun yaitu tahun 2006, 2007 dan 2008, masing-masing kabupaten di Provinsi Jambi telah menerima total penyaluran bantuan social hamper mencapai 5 Milyar Rupiah. Untuk tahun 2008, bantuan social yang diterima oleh masingmasing kabupaten dari Kementrian Negara Pembangunan Daerah Tertinggal (KPDT) adalah :

a. Kabupaten Sarolangun

$>$ Bantuan sosial melalui instrument/program P2SEDT (percepatan pembangunan sosial ekonomi daerah tertinggal). Peningakatan kelembagaan di 10 desa dengan membentuk Kader Penggerak Pembangunan Satu Bangsa (KPPSB) dimasing-masing desa.

$>$ Bantuan social melalui instrument/program P2IPDT (percepatan pembangunan infrasturktur pedesaan daerah tertinggal). Peningkatan infrasturktur listrik PLTS dan peningkatan infrastruktur perumahan bagi suku anak dalam.

$>$ Bantuan social melalui instrument/program P4DT(percepatan pembangunan pusat pertumbuhan daerah tertinggal)

b. Kabupaten Tanjung Jabung Timur

$>$ Bantuan social melali instrumen/program P2SEDT .

$>$ Bantuan social melalui instrument/program P2IPDT.

$>$ Bantuan sosil melalui istrumen/program P4DT. Pengadaan bibit padi dan pengadaan bibit sapi.

Guna meningkatkan koordinasi, sinergitas dan harmonisasi, strategi, rencana dan program percepatan pembangunan daerah tertinggal secra operasional maka pada masingmasing tingkatan pemerintahan dibentuk Tim Koordinasi Percepatan Pembangunan Daerah tertinggal (TKPPDT). TKPPDT Provinsi Jambi ditetapkan berdasarkan Surat Keputusan Gubernur Jambi No. 306/Kep.Gub/BAPPEDE/2008 tanggal 11 September 2008. TKPPDT Provinsi Jambi merupakan forum lintas SKPD (satuan kerja perangkat daerah) dalam provinsi Jambi sebagai wadah koordinasi dalam rangka percepatan pembangunan daerah tertinggal (PPDT) di wilayah Provinsi Jambi. TKPPDT Provinsi Jambi dipimpin oleh ketua Bappeda Provinsi Jambi.

TKPPDT Provinsi Jambi bertugas untuk malakukan langkah-langkah nyata guna mempercepat pembangunan daerah tertinggal dengan mengacu kepada :

$\checkmark$ RPJM (Rencana Pembangunan Jangka Menengah)

$\checkmark$ STRANAS PPDT (Strategi Nasional Percepatan Pembangunan Daerah Tertinggal)

$\checkmark$ STRADA PPDT (Strategi Daerah Percepatan pembangunan Daerah Tertingal) Provinsi Jambi.

Dengan adanya Program P2SEDT ini dan kesinambungan program diharapkan mampu mengupayakan agar hasil-hasil pelaksanaan kebijakn dan program pembangunan daeah tertinggal dapat terpelihara dan dikembangkan sehingga berdampak bagi kesejahteraan masyarakat. Penguatan kelembagaan masyarakat melalui instrument /program P2SEDT harus dijamin dapat memberi manfaat kepada masyarakat secara berkesinambungan. Baik dalam bidang fisik maupun non fisik.

\section{Evaluasi Program P2SEDT}

Berdasarkan sebaran wilayahnya, sebanyak 123 kabuapten atau 63 persen daerah tertinggal berada di kawasan Timur Indonesia, 58 kabuapten atau 28 persen berada di plau Sumatra, 18 kabupaten atau 8 persen berada di pulau jawa dan bali. Dilur kategori ketertinggalan tersebut, juga terdapat sejumlah kawasan yang dihuni oleh Komunitas Adat Terpencil yaitu kelompo social budaya yang bersifat local dan terpencar yang pada umumnya 
kawasan tersebut masih belum tersentuh oleh jaringan dan pelayanan social, ekonomi bahkan pemerintahan.

Dalam perjalanannya, sejak tahun 2004-2007 evaluasi terhadap pembangunan di daerah tertinggal terus dilakukan. Evaluasi tersebut mencakuo variable, seperti variable ekonomi local, pengembangan SDM, pembangunan infrastruktur, aksestabilitas, keuangan dan kareteristik kedaerahan yang diukur dengan jumlah desa yang rawan dengan gempa bumi, jumlah desa yang rawan tanah longsor, jumlah desa yang rawan banjir, jumlah desa yang rawan bencana lainnya, jumlah desa yang berada dikawasan lindung, jumlah desa yang berlahan kritis, jumlah desa yang terjadi konflik 1 tahun terakhir.

Dari pola kebijakan pembangunan ke daerah tertinggal, melalui berbagai variable tersebut, dapat dikatakan bahwa pola kebijakan dan pola pendekatan dalam pembangunan daerah tertinggal masih belum mampu berjalan secara maksimal. Hal ini dikarenakan belum adanya sikap alternative bagi daerah tertinggal dalam aspek kebijakan, peencanan, penganggaran, pelaksanaan, koordinasi dan pengendalian. Serta belum adanya keselarasan dan keterpaduan dintara 3 (tiga) level pemerintahan, yaitu pemerintah, pemerintah Provinsi dan pemerintah kabupaten dalam penentuan agenda kegiatan, perncanaan, pelaksaaan dan monitoring dan evaluasi pembangunan daerah tertinggal.

Namun, setelah 3 tahun perjalanan Kabinet Indonesia Bersatu, telah banyak kemajuan yang dcapai, khusunya didalam pelaksanaan pembangunan daerah tertinggal. Evaluasi daerah tertinggal dilakukan dengan menggunakan :

\section{Indeks ketertinggalan}

Cara ini dilakukan dengan menghitung indeks ketertinggalan relative terhadap seluruh kabupaten/kota dalam mengelompokkan Daerah Tertinggak kedalam 5 derajat ketertinggalan, yaitu :

Sangat parah

$>$ Sangat tertinggal

$>$ Tertinggal,

$>$ Agak tertinggal

$>$ Tidak tertinggal atau maju

Nilai Indeks ketertinggalan sendiri dilihat perkembangannya yaitu dengan membandingkan kondisi Tahun 2004 dengan kondisi tahun 2007. Adapn Indokator ketertinggalan adalah :

\section{Ekonomi}

a. Prosentase Penduduk Miskin

Adalah ratio penduduk miskin kabupaten terhadap jumlah total penduduk kabupaten.

b. Indeks Kedalaman kemiskinan

Adalah Prosentase kedalaman kemiskinan terhadap garis kemiskinan.

\section{Sumberdaya Manusia (SDM)}

a. Tenaga kerja

Adalah prosentase penduduk menganggur

b. Kesehatan

1. Prosentase desa balita kurang gizi

2. Prosentase desa non balita kurang gizi

3. Angka kematian bayi

4. Umur Harapan Hidup

5. Jumlah prasarana kesehatan per 1000 penduduk

6. Jumlah dokter per 1000 penduduk

7. Rata-rata jarak pelayanan prasarana kesehatan/Jarak Desa ke Prasaran Kesehatan (Kilometer ) 
8. Prosentasi Jumlah desa yang sulit dan sangat sulit untuk mencapai prasarana kesehatan

c. Pendidikan

1. Angka melek huruf (Prosentase yang bisa baca per jumlah penduduk)

2. Rata-rata Jumlah Murid DO (Drop Out) SD Per 1000 Penduduk

3. Jumlah SD dan SMP per 1000 Penduduk

4. Rata-rata Jarak SD dan SMP (Kilometer) pada kabupaten terdekat (Bila di kabupaten tersebut tidak ada SD dan SMP)

\section{Infrastruktur}

a. Transportasi

- Desa dengan jenis permukaan jalan terluas (Apal/beton, Diperkeras, Tanah, Lainnya)

b. Komunikasi

- $\quad$ Prosentase rumah tangga pengguna telepon

c. Ekonomi

- $\quad$ Prosentase rumah tangga pengguna listrik

- Jumlah Bank Umum

- Jumlah Bank Perkreditan Rakyat

- $\quad$ Jumlah Desa yang mempunyai pasar non permanen

\section{Kelembagaan keuangan daerah (Celah Fiskal)}

Adalah selisih penerimaan keuangan daerah (diluar DAK, pinjaman daerah dan sisa anggaran tahun lalu) dengan belanja pegawai

\section{Aksesibilitas}

Adalah rata-rata jarak dari kantor desa ke Kabupaten

\section{Karakteristik Daerah}

a. Prosentase desa gempa

b. Prosentase desa rawan longsor

c. Prosentase desa rawan banjir

d. Prosentase desa rawan bencana lain

e. Prosentase desa di kawasan lindung

f. Prosentase desa lahan kritis

g. Prosentase desa konflik (1 tahun terakhir)

Faktor-faktor Penyebab Ketertinggalan adalah :

1. Geografis

2. Sumberdaya alam

3. Sumber daya manusia

4. Kelembagaan keuangan

5. Pasca Bencana Alam/sosial

\section{Dengan posisi kuadran.}

Cara ini dilakukan dengan melihat posisi kuadran daerah tertinggal serta membandingkan antara kondisi tahun 2004 dengan tahun 2007. Dengan melihat posisi kuadran ini maka :

a. Akan diketahui pola pergerakan pembangunan daerah tertinggal.

b. Memudahkan perumusan kebijakan.

c. Memudahkan pengelompokkan berdasarkan isu utama yaitu derajat ketertinggalan dan percepatan. 


\section{d. Monitoring kebijakan.}

Berdasarkan evaluasi tiga tahun pembangunan daerah tertinggl yang dilakukan KPDT bersama Bappenas, diketahui bahwa dari 199 kabupaten tertinggal tahun 2004, dalam kategori sangat parah (9 kabupaten), sangat tertinggal (50 kabupaten), tertinggal (54 kabupaten) dan agak tertinggal (88 kabupaten). Kemudian pada tahun 2007 diketahui bahwa kategori sangat parah (11 kabupaten), sangat tertinggal (50 kabupaten), tertinggal (53 kabupaten), agak tertinggal (57 kabupaten) sehingga didapatkan hasil bahwa terdapat 28 kabupaten yang sudah dapat kelar dari kategori tertinggal.

Ke 28 daerah yang lepas dari ketertinggal tersebut adalah Madiun, Kuantan Singingi, Dharmasraya, Tana Toraja, Takalar, Gunung Mas, Aceh Tengah, Situbondo, Pamekasan, Pinran, Bireuen, Bonowoso, Sambas, Kupang, Aceh Utara, Malinau, Barito Kuala, Nunukan, Aceh Besar, Wonogiri, Karangasem, Belitung, Lahat, Jayapura, Bangkalan, Kuti Barat, Pidie dan Natuna. Gambaran ini semakin memperbesar hati, bahwa segala upaya kita ini tidaklah sia-sia.

Pemerintah perlu mengkaji kembali apa yang menjadi penyebab dari ketertinggalan yang dihadapi di daerah-daerah tertinggal. Baerdasarkan hasil evaluasi paruh waktu RPJMN 2004-2009, beberapa hal yang menjadi penyebab ketertinggalan suatu daerah anatara lain :

1. Pelaksanaan kebijakan pembangunan yang masih relative sektoral/parsial.

2. Penyusunan kebijakan yang jangka pendek atau berorientasi proyek.

3. Kecendrunga pelayanan public yang mengarah pada orientasi politis.

4. Belum dimasukkannya dimensi keruangan/spasial dalam perencanaan pembangunan daerah tertinggal yng terkait dengan belum tegasnya keterkaitan fungsional anatar daerah tertinggal dengan kawasan strategis dan cepat tumbuh.

Berdasarkan data diatas dapat disimpulkan bahwa pemerintah cukup berhasil daam mengentaskan kemiskinan walaupun belum mencapai hasil yang maksimal. Semuanya juga tidak lepas dari dukungan-dukungan masyarakat dimana adanya kerjasama yang baik didalamnya. Kementrian Negara Pembangunan Daerah Tertinggal (KPDT) sudah berhasil menjadikan sebanyak 28 kabupaten keluar dari ketertinggalnya dan telah berhasil mengintervensi ebanyak 30 kabupaten dan diharapkan dapat lepas dari ketertinggalannya pada tahun 2008.

Untuk operasional kebijakan, KPDT memiliki instrument yang terdiri dari :

1. Percepatan pembangunan Daerah Tertinggal dan Khusus.

2. Percepatan Pembangunan Kawasan Produksi Daerah Tertinggal.

3. Percepatan Pembangunan Infrastruktur Perdesaan Daerah Tertinggal.

4. Percepatan Pembangunan Sosial Ekonomi Daerah Tertinggal.

5. Percepatan Pembangunan Wilayah Perbatasan.

6. Percepatan Pembangunan Pusat Pertumbuhan Daerah Tertinggal.

Dengan adanya strategi dari program P2SEDT diharapkan mampu mengurangi tingkat kemiskinan di Indonesia dengan melibatkan semua pihak diantaranya :

a. Di Era Otonomi Daerah ini pelaksana utama pembangunan daerah tertinggal adalah Kabupaten.

b. Provinsi berkewajiban melakukan koordinasi dan integrasi agar terjadi sinergi kebijakan pembangnan daerah tertinggal diwilayhnya.

c. Sector (kementrian/lembaga) berkewajiban melaksanakan percepatanpembangunan di daerah tertinggal sesuai dengan prioritas sector masing-masing. Kementrian Negara Pembangunan Daerah Tertinggal berkewajiban melakukan perumusan kebijakan dan koordinasi pelaksanaan kebijakan dibidang pembangunan daerah tertinggal serta menyelenggarakan operasioanalisasi kebijakan dibidang bantuan infrastruktur perdesaan. 


\section{Daftar Pustaka}

Buku :

Hikmat, Harry. 2004. Strategi Pemberdayaan Masyarakat. Penerbit : Humaniora. Bandung Materi Kuliah Kemiskinan yang disampaikan Oleh Dr. Ambar Widaningrum. 2009. Dosen Tetap Magister Administrasi Publik. UGM

Usman, Sunyoto. 2008. Pembangunan dan Pemberdayaan Masyarakat. Pustaka Pelajar :Yogyakarta. 